Article

\title{
The Future of Sustainable Urbanism: Society-Based, Complexity-Led, and Landscape-Driven
}

\author{
Rob Roggema \\ Faculty of Design, Architecture and Building, University of Technology Sydney, Ultimo 2007, Australia; \\ rob.roggema@uts.edu.au; Tel.: +61-4-2388-1377
}

Received: 17 July 2017; Accepted: 13 August 2017; Published: 15 August 2017

\begin{abstract}
This article discusses the question: where to with sustainable urbanism? It includes a historic review of the concept of sustainable urbanism and reviews of recent literature in the field of eco-cities. Through these reviews, it deliberately interrogates new pathways for sustainable urbanism. The result of this investigation is the insight that there are six design principles that are required to create a sustainable city: a design in which cycles are closed, redundancy is built in, anti-fragility is created, citizens are seen as (design) experts, the landscape is used as the basis, and innovative, rule-breaking designs are developed. These six design principles are then captured in three comprehensive concepts, which together support the design of a sustainable city: the design approach needs to be a (1) society-based; (2) complexity-led, and (3) landscape-driven design approach.
\end{abstract}

Keywords: sustainable urbanism; green city; eco-city; complexity; society; landscape

\section{Introduction}

\subsection{Aims}

Most of current urbanism is based on a technological paradigm in which the quantification of elements such as housing, jobs and parking spaces, standards, and regulations seem more important than achieving resilience. These kinds of urbanism are strongly economically driven and money-based. Recent developments, such as smart cities, with their focus on data and technology, often deepen this technological paradigm, hence adding vulnerability to urban systems. The urban social and natural systems are seldom capable of dealing with sudden shocks, which are bound to occur at an increasing rate [1].

In the future we need to deal with a triplet of uncertainties [2]:

- The first of this triplet are developments, which are uncertain by nature. Examples of these, often referred to as wicked problems [3-5], are climate change, mass migration, and disruptive technological developments. These are impossible to predict and are therefore inherently uncertain;

- A second element consists of enforced uncertainties. Several sustainability transitions, such as the transition towards a green economy [6] or a low-carbon energy system $[7,8]$ are deliberately enforced by international agreements and national policies. This type of uncertainties will impact the urban system. In order to accommodate these transitions the city itself needs to transform;

- Thirdly, there is uncertainty that stems from being exposed to the aforementioned two elements: exposure to uncertainties. For instance, the urbanisation of the global population continues [9], which means an increasing number of people live in cities. At the same time, most cities worldwide are located in vulnerable, exposed areas [10]. Together, this means that the number of people that will have to deal with uncertainties is rapidly increasing. 
Because of this triplet of uncertainties, a definition of the future of eco-urbanism is required: urbanism that deals with the above-mentioned triplet of uncertainties, using both advanced technologies, the laws of nature, and self-organizing adaptive systems. This article identifies how this future of eco-urbanism can be achieved.

\subsection{Methods}

The method of this research consists of two reviews, the development of a common framework, and concludes with a definition of sustainable urbanism. First, a review of the history of sustainability in urbanism was carried out. The second review focused on a broad range of 'eco'-initiatives, such as regenerative cities, eco-cities, the Biosphere project, One Planet, and others. After these reviews, a common denominator, missing links, and gaps were identified and used to define a congruent future of sustainable urbanism.

\subsection{Findings}

First of all, the author did not find a unified or coherent perspective on sustainable urbanism. If we want to use the design of the city to deal with future disruptions resulting from climate impacts, migration, economic change, or any other threat, this design should allow the city to transform and adapt to changes. Looking at the city as a complex adaptive system, the capability to adapt to sudden, unprecedented changes and to deal with uncertainty is therefore essential.

Six design principles have been identified, which are needed to support the design of a sustainable city. These design principles are:

(1) Close cycles at the lowest possible scale;

(2) Build redundancy in the design;

(3) Create anti-fragility;

(4) See citizens as (design) experts;

(5) Use the landscape as the basis for urban growth;

(6) Develop innovative, rule-breaking designs.

These six design criteria are then consolidated into three comprehensive 'concepts' for the design of sustainable cities: society-based, complexity-led, and landscape-driven, which will be extensively described in this article.

The society, consisting of citizens and governmental and industry institutions, is seen as a pool of experts and ideas to co-feed the planning agenda. The research agenda is complimentary with the society-based agenda.

The complexity of cities needs to be deconstructed in approximately 15 separate layers before it can be reconstructed at the neighborhood level.

The landscape should form the basis for urban growth in order to create cities that exist in harmony with landscape-processes, which on their turn determine the shape of the city.

\subsection{Conclusions}

The main conclusion of this article is these three comprehensive concepts, and the six design principles can be used in the design of more sustainable cities at every scale.

\section{Methods}

The methodology in this article is based on two extensive literature reviews, one on the history of sustainability in urbanism and one on green, or ecological, urbanism or 'eco'-urbanism. Both topics have been studied extensively, and used recent journal articles, books, and websites to collect the information needed to present a coherent analytical reasoning.

Grounded theory has been used as the core methodology. The theoretical proposition has been built up from all its parts, in a constant process of shaping, modifying, and redesigning the theory. 
This research approach does start with its parts (the findings from literature reviews), identifies key points and concepts (the six principles), which in their turn have informed theory forming (the three overarching concepts), hence it reflects the principles of Grounded Theory. As a general definition of Grounded Theory, it is a methodology developed by Glaser and Strauss [11] to construct a theory derived from qualitative analysis of data [12]. In Grounded Theory, the research guides data collection. The core here is theoretical sampling, which is concept driven. Out of the data, concepts are developed, which subsequently direct the collection of data. Only relevant concepts are elaborated further and integrated, linking categories around core categories, which are refined and trimmed into a theoretical construct. In essence, Grounded Theory can be brought back to three key steps. In the first step, key points (the rudiments of key principles) are identified and around these key points data are collected. In the second step, these key points are connected in concepts (the six principles), and the third step integrates the concepts in a theoretical construct (the three overarching concepts). The attractiveness of this research theory was that there was no fixed pattern beforehand, but it focused on the creation of new insights and the theory emerged during the process.

From these reviews, six design principles for sustainable urbanism emerged, which define the identification, design, and realisation of resilience in urban areas at every scale. The principles are interrelated and are captured in three comprehensive concepts: sustainable urbanism has to be based in society, led through a complexity lens, and design should be based in the landscape.

\section{Results}

\subsection{Review of the History of Sustainability in Urbanism}

Looking back in time, sustainability has not always been a central theme in urbanism. 'The term 'sustainable urbanism' encompasses topics of sustainability related to the entire process of city development and management, while sustainable urban design sits somewhere within that. Sustainable urban design is not necessarily a clearly delineated subset of sustainable urbanism, but instead can be thought of as focus area within it that is concentrated around issues of design, while still maintaining strong links to the other realms such as planning, engineering, real estate, and policy [13]. The famous image of the architect eating the landscape, by Malcolm Wells, illustrates the way urbanism was seen for a long time: as a destroyer of natural values. Girardet [14] was one of the first to acknowledge the importance of an integrated approach to developing cities in a sustainable way. He connected themes such as looking at cities as ecosystems, the footprint of cities, urban heat islands, and others with urban design schools, such as the garden city movement [15], the modern city of Le Corbusier [16], Frank Lloyd Wright's Broadacre city [17], and megacities in general [18,19]. His pledge for convivial cities, the role of citizens and the local scale, and the attention for health, greening the city, renewable energy and recycling, and sustainable forms of mobility [14], are still relevant. Since then, many perspectives, visions, and conceptual practices have been developed, each of them taking sustainability into account in the planning and the design of cities. In the last 20 years, a number of theories or ideologies have influenced thinking about (sustainable) urbanism. Scholars such as Farr [20], acknowledging a strong shift towards integration of ecological analyses in urbanism, Beatley, focusing on ecologically-based land use planning [21] and integrating nature into urban design and planning [22], Mostafavi [23], deliberating on ecological urbanism, Waldheim [24], launching landscape urbanism in which landscape supplants architecture as the basis of urban design, and Newman et al. [25], elaborating on the resilience of the city, as well as Duany et al. [26], proposing an extensive manual on smart growth, and Haas [27], defining a wide range of principles for planning of sustainable and resilient cities, have all covered ground related to building a framework for sustainable urbanism. However, much of the literature on sustainable urban design still lacks grounds for holistically relating the different aspects of urban design [13]. Taking these readings as the starting point of thinking, sustainability in urbanism has been divided in seven distinctive periods [2] which illustrate how the concept of sustainable urbanism has evolved over time. 
From the early days when aesthetics were defined by Vitruvius [28] as not only beautiful (venustas), but also solid (firmitas) and useful (utilitas) [29], urban sustainability is defined as a multi-layered concept and aesthetics is equally important as economic viability or ecological value, not more or less important [30]. Sustainability is not similar to environmental quality. A high environmental quality alone does not guarantee a high degree of sustainability. Similarly, an urban environment with a high environmental quality or a high economic value, but without beauty is not considered sustainable either.

After this, periods such as rationalism and conceptualism can be distinguished. Rationalism assumes knowledge will implicitly lead to solutions. An expert planner or the designer 'who knows it all' [31] is required to translate this knowledge into functional urban environments. The shape of the city follows the land use, or 'form follows function' [32], and engineers play an important role in the final outcome of the design process. In this context sustainability becomes a quantifiable aspect and standards and regulations were introduced, such as for clean water, air, and soil. In the conceptualism period, the water system, the soil, and nature are used as layers [33], an approach that is widely used in the Netherlands [34]. The abiotic, biotic, and anthropogenic layers shape the landscape. The layers aim to separate different dynamics of use. Where the subsoil is seen as changing extremely slowly, and the networks change at a moderate pace, the occupation patterns can change relatively rapidly. It assumes the occupation patterns are nested in the infrastructure networks, which in turn are embedded in the substrate system [35]. In the casco-concept, which is based on this thinking, these spatial dynamics are separated [36]. In the concept called 'the strategy of the two networks', higher dynamic uses (traffic, industries, intensive forms of agriculture) are linked to the transportation network and the lower dynamic uses (nature, green, water, residential) to the water network $[37,38]$.

In the negotiatism period, sustainability is seen as a discussable ambition in the planning process. New methods are developed to target sustainability ambitions, such as the DCBA-method [39], in which every urban design aspect requirement is set for level D to A, D being the highest. Over time, the negotiation process evolved into advanced participatory processes, in which engaged citizens could co-design and co-create $[40,41]$ the sustainability of their direct environment $[42,43]$. In these sessions, the wisdom of the crowd [44] is used to identify future strategies for a sustainable spatial development.

Looking at the city as an ecosystem [45] is the key of the period in which urban metabolism [46-50] defines the city in terms of its flows. When the layer approach is combined with this system's thinking, a comprehensive model for urban environmental design [51] emerges. The degree to which the system is able to deal with the flows, or networks of traffic, water, energy, and materials, determines the level of sustainability of the system. The design of the city is based on ways in which depletion of resources and production of waste are reduced, and in which resources can be reused and recycled within the city.

The most recent periods, emergism and anti-fragilism focus on the city as a responsive system, in which self-organisation and the adaptive capacities of complex systems determine urban processes. Emergism takes complexity [52-56] as the input for the design of cities [57,58]. Self-organisation and emergence are key concepts, and are used to design interventions in the system to achieve certain changes. These concepts are common in nature and can be used in designing future cities and landscapes that are more adaptable [59]. The designer acts as a facilitator of the process of change, intervening at specific places or times to initiate a change in the system. Approaches such as eco-acupuncture [60,61] and Swarm Planning [58] aim to design small interventions in an existing urban precinct or landscape to transform the area and become more resilient. In order to apply these principles, physical elements in the city or the landscape need to be made moveable [62] and capable of responding to different paces of change that might occur in the city: fast, slow, or sudden [63]. In order to adapt to new circumstances urban systems need to become agile [64]. Rather than only responding to change by coping with it, urban environments can actually become stronger than before through their response to climate events. This concept is called anti-fragility. 'Ant-fragility is defined as a convex response to a stressor or source of harm (for some range of variation), leading to a 
positive sensitivity to increase in volatility (or variability, stress, dispersion of outcomes, or uncertainty, what is grouped under the designation "disorder cluster")' [65], and offers interesting opportunities. For instance, if the city can create a stronger flood defence by itself once a flood occurs, the city becomes safer. Anti-fragilism is not a common approach in urbanism yet. However, the current combination of increasing uncertainties and unalterable cityscapes places urban population increasingly at risk. Therefore it is necessary to investigate the solutions anti-fragility might bring to urbanism.

Learning from the history of sustainability in urbanism, several key-concepts stand out. The concepts developed to create sustainable framework with the landscape as a basis, such as the layer approach [34,35], the casco-concept [36], and the Two Networks strategy [37,38], have determined much of the work and research being carried out in landscape architecture.

The engagement of communities in the planning and design of urban environment is another key concept which determines the sustainability, support, and acceptance of urban change amongst residents. Recent concepts such as co-design and co-creation allow for a broad spectrum of expertise sets in the design process, which stimulates the development of new and innovative design ideas and new knowledge.

The view of the city as an ecosystem has changed the way we look at urban change and design. The metabolism and design of flows made it possible to discuss the sustainability of the city as a whole, and close the cycles of energy, water, and materials.

More recently, the city is seen as a complex adaptive system and this implies that adaptation and resilience of the city can be discussed as core characteristics. The adaptivity of the city can be influenced through strategic design interventions supporting self-organisation. Adaptation requires creating space to adapt, hence this concept advocates redundancy ('space for the unknown') in the urban realm.

A future avenue to increase the strength of the city is to create anti-fragile environments, which grow under influence of external impacts.

These key characteristics derived from the analysis are summarised in Table 1. They lead to six principles that serve as a basis for design: closing cycles, innovative designs, create space for the unknown, anti-fragility, people's engagement, and taking the landscape as basis for design. These principles are regarded under the larger comprehensive concepts such as society, complexity, and landscape.

Table 1. Sustainable urbanism translated in principles and overarching concepts.

\begin{tabular}{cccc}
\hline Phase & Concept & Principle & Overarching \\
\hline $\begin{array}{c}\text { Aesthetics } \\
\text { Rationalism }\end{array}$ & & & \\
\cline { 1 - 3 } Negotiatism & $\begin{array}{c}\text { Co-design } \\
\text { Co-creation }\end{array}$ & $\begin{array}{c}\text { People } \\
\text { Innovative design }\end{array}$ & \multirow{2}{*}{ Society } \\
\cline { 1 - 3 } Emergensim & Interventions & Innovative design & \\
\cline { 1 - 3 } Ecosystem based & Metabolism & Close cycles & \multirow{2}{*}{ Complexity } \\
\cline { 1 - 2 } Antifragility & Interventions & Space for the unknown & \\
\cline { 1 - 2 } Emergenism & $\begin{array}{c}\text { Layers Approach } \\
\text { Casco Concept }\end{array}$ & Landscape as basis & \\
\cline { 1 - 2 } Conceptualism & Two Network Strategy & & \\
\hline
\end{tabular}




\subsection{Review of Eco-Initiatives in the Built Environment}

\subsubsection{Drivers for Green, or 'Ecological', Urbanism}

Green urbanism is, by definition, interdisciplinary, as in 'ecological design', which has been and will be interdisciplinary, not the property of any single profession or movement [66]. Where ecologists look at the size of the ecological footprint, public health focuses on the exposure to pollution, and economists have their eye on the differences in price of real estate, green urbanism unites these views [67]. Green urbanism makes the effort to minimize the use of energy, water, and materials at each stage of the city's or district's life cycle [68]. In a new era of uncertainty energy, water and food supply are critical. Humans create a world of increasingly non-calculable uncertainty with the same speed of its technological developments [69]. For eco-urbanism, six driving forces are distinguished: They can be driven by environmental challenges, emerge out of socio-economic pressure, are seen as a business opportunity, be part of cultural branding, evolve out of political leadership, and could be instigated by international co-operation [70]. The development of the eco-city, based on a different combination of these drivers, emerged in three phases (Table 2): after a normative and regulatory phase, the current discourse is based on innovation.

Table 2. Three phases of eco-city development (adapted from 70).

\begin{tabular}{|c|c|c|c|}
\hline & Phase & Perspective & Means \\
\hline 1980 's & Grassroots, & Normativ & Environme \\
\hline 1992-early 2000 & Local and national experimentation & Regulatory, standardised & Standardized models \\
\hline 2000-present & Global expansion, mainstreaming & Innovation, conceptual & Technology and design \\
\hline
\end{tabular}

These three phases can be linked, with differences in the means to realize an eco-city: Environmental sustainability is used in the normative phase, models are used to standardize in the second phase, and, in the current period, sustainability is achieved through technology and design [71].

\subsubsection{Urban Design Principles}

Based on these driving forces for green urbanism, a series of principles can be defined (Table 3) and applied in a systemic and adapted way, requiring a specific approach for every unique site. The future of our society is not merely a technical matter of finding more eco-friendly energy solutions, but a question of holistic environmental and social sustainability, and identifying principles for healthy communities. Much of Green Urbanism is common sense urbanism [68].

Table 3. Principles for Green Urbanism (adapted from 68).

\begin{tabular}{|c|c|}
\hline Principle & Aspects \\
\hline Climate and context & $\begin{array}{l}\text { Site's climate conditions, orientation and compactness, landscape, topography and } \\
\text { resources, maintain complexity, own methods, and tailored strategies for every district } \\
\text { take advantage of local potentials }\end{array}$ \\
\hline Renewable energy & $\begin{array}{l}\text { Availability of local renewables (energy potentials [72], city district as a producer of energy, } \\
\text { distributed energy supply though decentralized systems, local storage, smart grid, energy } \\
\text { efficiency, co-gen, cascading exergy principles, intelligent building management. }\end{array}$ \\
\hline Zero-waste & $\begin{array}{l}\text { Circular, closed loop, turn waste into resource, reduce, reuse, recycle, and compost waste } \\
\text { to produce energy, remanufacturing, balance in nitrogen cycle }\end{array}$ \\
\hline Water & $\begin{array}{l}\text { Reduce consumption, efficiency of use, water quality, aquatic habitats, city as a water } \\
\text { catchment area, storm water retention and flood management, rainwater harvesting, local } \\
\text { treatment of waste-water, safe water and sanitation, algae, integrated urban water cycle } \\
\text { planning, black and grey water treatment, dual water systems, drought resistant crops }\end{array}$ \\
\hline $\begin{array}{l}\text { Landscape and urban } \\
\text { biodiversity }\end{array}$ & $\begin{array}{l}\text { Local biodiversity, habitat, ecology, wildlife rehabilitation, forest conservation, urban } \\
\text { vegetation, inner city gardens and urban agriculture, mitigating Urban Heat island effects, } \\
\text { tree planting, restoring stream and river banks, de-pavements, carbon storage }\end{array}$ \\
\hline
\end{tabular}


Table 3. Cont.

\begin{tabular}{|c|c|}
\hline Principle & Aspects \\
\hline $\begin{array}{l}\text { Local materials with less } \\
\text { embodied energy }\end{array}$ & $\begin{array}{l}\text { Advanced materials technology, local materials, modular prefabrication, lightweight } \\
\text { structures, disassembly, resource recovery, reuse building components }\end{array}$ \\
\hline $\begin{array}{l}\text { Passive design for } \\
\text { buildings and districts }\end{array}$ & $\begin{array}{l}\text { Low energy, zero-emission design, reduce energy use, compact solar architecture, } \\
\text { bioclimatic architecture, design for disassembly, solar architecture, flexibility in plans, } \\
\text { energy generating buildings }\end{array}$ \\
\hline $\begin{array}{l}\text { Local food and short } \\
\text { supply chains }\end{array}$ & $\begin{array}{l}\text { Local food production, regional supply, urban farming and agriculture, community and } \\
\text { allotment gardens, roof gardens, urban market garden, paper bags, recycling, } \\
\text { organic produce }\end{array}$ \\
\hline Identity and sense of place & $\begin{array}{l}\text { Public health, cultural identity, urban heritage, air quality, distinct environment, grassroots } \\
\text { strategies, affordable studio space, creativity of government and citizens, health, activities } \\
\text { and safety }\end{array}$ \\
\hline $\begin{array}{l}\text { Urban governance } \\
\text { and leadership }\end{array}$ & $\begin{array}{l}\text { Evolutionary and adaptive policies, decision making, and responsibility shared with } \\
\text { empowered citizenry, enabling citizens, updating building codes, improve planning } \\
\text { participation, integrated public awareness, legislating controls on density and urban } \\
\text { sprawl, support high quality densification, finance low-to-no-carbon pathways, eliminate } \\
\text { fossil fuel subsidies, certify urban development projects }\end{array}$ \\
\hline
\end{tabular}

\subsubsection{Eco-City Typologies}

'Full awareness of problems posed by climate change and consumption of fossil fuel is of equal importance and just as far reaching, raising the possibility of entirely new city models and typologies that are likely to emerge' [73]. For instance, Kahn defines a green city as a metropolis, which has a core area containing a substantial population nucleus, surrounded by adjacent communities with a high degree of social and economic integration. Green stands for cities that have clean air and water, pleasant streets and parks, are resilient in the face of natural disasters, and have a low risk at infectious disease outbreaks, and they encourage green behavior [67].

Haughton [74] distinguishes the following four models of cities and their relations to their environmental hinterlands:

- Self-reliant cities: intensive internalization of economic en environmental activities, circular metabolism, bioregionalism, and urban autarky;

- Redesigning cities and their regions: planning for compact, energy efficient city regions;

- Externally dependent cities: excessive externalization of environmental cost, open systems, linear metabolism, and buying in additional carrying capacity;

- Fair Share cities: balancing needs and rights equitably with regulated flows of environmental value and compensatory systems;

Focusing more specifically on sustainable urbanism, De Jong et al. [75] distinguish an additional six types of cities:

- The sustainable city, which has a self-sufficient economic, social, and environmental system;

- The low carbon city is minimizing the human-inflicted carbon footprint by reducing or even eliminating the use of non-renewable energy resources; 
- The smart city [76], in which investments in human and social capital is coupled with investment in traditional (transport) and modern information and telecommunication infrastructure, generating sustainable economic development and a high quality of life while promoting prudent management of natural resources [77];

- The knowledge city integrates cities that physically and institutionally combine the function of a science park with civic and residential functions [78];

- The resilient city in which a predictive model of urban systems is built through three interconnected components of uncertainty: adaptation, spatial planning, and sustainable urban form (compactness, density, mixed land use, diversity, passive solar, greening, and renewal and utilization) [79], in order to deal with ecological problems, hazards and disasters, and shocks in urban en regional economies, through promoting urban governance and institutions [80];

- The eco-city aims to reconstruct cities in balance with nature, a city built within the principles of living within the means of the environment [81].

An eco-city is a human settlement modelled on the self-sustaining resilient structure and function of natural ecosystems. The eco-city provides healthy abundance to its inhabitants without consuming more (renewable) resources than it produces, without producing more waste than it can assimilate, and without being toxic to itself or neighbouring ecosystems. Its habitants' ecological impact reflects planetary supportive lifestyles; its social order reflects fundamental principles of fairness, justice, and reasonable equity [82]. Best practice examples of eco-cities in which these principles to a lesser or larger extend have been realised include the EVA Lanxmeer project in the Netherlands, Masdar ecocity in UAE, Hammarby-Sjöstadt in Stockholm, Sweden, and Hafencity in Hamburg, Germany.

The following dimensions of eco-cities are distinguished [83]:

- Sustainable development: meet the needs of the present without compromising the ability of future generations to meet their own needs [84];

- Bioregionalism: a region governed by nature not legislature [85];

- Community economic development: communities initiate their own solutions to their common economic problems;

- Appropriate technology: enhance self-reliance of people;

- Social ecology: committed citizenry cutting across class and economic barriers to address dangers;

- Green movement: community self-reliance, quality of life, harmony with nature, and decentralization and diversity [86];

- Ubiquitous eco-city: international knowledge transfer, carbon discourse, smart city and ecological cities as economic cities [87,88].

The regenerative city relies primarily on local and regional food supplies, is powered, heated, cooled, and driven by renewable energy, reuses resources, and restores degraded ecosystems [89]. The aim of the regenerative city is to be able to regenerate the natural resources it absorbs, consisting of four regenerations: Regeneration of Resources (From linear to circular flows), Regeneration of Natural Capital and Urban Ecosystems (from consuming to 'prosuming'), Regeneration of Urban Spaces (from Sprawled to Dense) and Regeneration of Communities (from Passive to Active engagement) [90]. ReGen villages engineer and facilitate the development of integrated and resilient neighborhoods that power and feed self-reliant families. The Internet of Things (IoT) enables thriving communities with surplus energy, water, and organic food in the aggregate become asset classes that can amortize and reduce mortgage payments [91].

\subsubsection{Urban Design Characteristics of Eco-Cities}

More detailed characteristics of sustainable urban environments can be distinguished, such as BedZED (Table 4, [92]), and as described by Kenworthy [93]:

- Compact mixed use urban form; 
- Natural environment permeates the city's spaces;

- Transit, walking and cycling infrastructure;

- Environmental technologies for water, energy, and waste;

- City centers are human centers, with access other than automobile;

- High quality public realm;

- Legible, permeable, robust varied, rich, visually appropriate, and personalized physical structure;

- Innovation, creativity, and uniqueness create economic performance;

- Visionary planning through 'debate and decide'.

Table 4. BedZED's One Planet Living principles for design [92].

\begin{tabular}{cl}
\hline Principle & \multicolumn{1}{c}{ Design } \\
\hline Health and happiness & $\begin{array}{l}\text { Encouraging active, social, meaningful lives to promote health } \\
\text { and wellbeing }\end{array}$ \\
\hline Equity and local economy & $\begin{array}{l}\text { Create safe equitable places to live and work, which support local } \\
\text { prosperity and international fair trade }\end{array}$ \\
\hline Culture and community & $\begin{array}{l}\text { Nurturing local identity and heritage empowering communities and } \\
\text { promoting a culture of sustainable living }\end{array}$ \\
\hline Land and nature & Protecting and restoring land for the benefit of people and wildlife \\
\hline Sustainable water & $\begin{array}{l}\text { Using water efficiently, protecting local water resources and reducing } \\
\text { flooding and drought }\end{array}$ \\
\hline Local and sustainable food & $\begin{array}{l}\text { Promoting sustainable humane farming and healthy diets high in local } \\
\text { seasonal organic food and vegetable protein }\end{array}$ \\
\hline Travel and transport & $\begin{array}{l}\text { Reducing the need to travel, encouraging walking, cycling and } \\
\text { low-carbon transport }\end{array}$ \\
\hline Materials and products & $\begin{array}{l}\text { Using materials from sustainable sources and promoting products, which } \\
\text { help people reduce consumption }\end{array}$ \\
\hline Zero waste & $\begin{array}{l}\text { Reducing consumption re-using and recycling to achieve zero-waste and } \\
\text { zero pollution }\end{array}$ \\
\hline Zero carbon energy & $\begin{array}{l}\text { Making buildings and manufacturing energy efficient and supplying all } \\
\text { energy with renewables }\end{array}$ \\
\hline
\end{tabular}

Learning from the review of eco-city literature, many different concepts, models, and principles arise. Depending on the phase of development, several urban typologies are distinguished, which each focus on different objects. The objects can be grouped in flows, climate and landscape, transport and densities, and social aspects (Table 5). These groups can be translated in principles for urbanism, to close the cycles, base the design on the landscape, involve people in a co-creation process, and enhance innovation. 
Table 5. Eco-cities concepts translated in principles.

\begin{tabular}{|c|c|c|c|}
\hline Phase & City & Object & Principle \\
\hline \multicolumn{4}{|l|}{ Environmental standard } \\
\hline \multirow{5}{*}{ Standardised models } & Sustainable city & Renewable energy & \multirow{5}{*}{ Flows/close cycles } \\
\hline & Self-reliant city & Low embodied energy & \\
\hline & $\begin{array}{l}\text { Resilient city } \\
\text { Regenerative city }\end{array}$ & Passive design & \\
\hline & Carrving capacity, metabolism & Food & \\
\hline & zero-low-carbon city & Water & \\
\hline \multirow{5}{*}{ Technology and design } & Bioregional city & Climate & \multirow{5}{*}{ Landscape-based design } \\
\hline & Green/Ubiquitous Eco-city & Landscape and biodiversity & \\
\hline & Smart city & & \\
\hline & Redesign of city & $\begin{array}{l}\text { Densification } \\
\text { Transport and travel }\end{array}$ & \\
\hline & Knowledge city & & \\
\hline \multirow{4}{*}{$\begin{array}{c}\text { Fair share/Equity and local } \\
\text { economy/Community } \\
\text { development }\end{array}$} & \multirow{4}{*}{$\begin{array}{c}\text { Social ecology } \\
\text { Health \& happiness } \\
\text { Cultural community }\end{array}$} & Liveability & People, co-creation \\
\hline & & $\begin{array}{l}\text { Local production } \\
\text { Identity }\end{array}$ & Innovative design \\
\hline & & Uber governance & People, co-design \\
\hline & & Education & People \\
\hline
\end{tabular}

\section{The Future of Sustainable Urbanism}

On the basis of the reviews of a history of sustainable urbanism and the literature on green cities, or eco-cities, six general principles for designing a sustainable city are defined: (1) close cycles at the lowest possible scale; (2) build redundancy in the design; (3) create anti-fragility; (4) see citizens as (design) experts; (5) use the landscape as the basis for urban growth; and (6) develop innovative, rule-breaking designs. Bringing the analyses of the history of sustainability in urbanism and the theory of eco-cities together (Table 6), three comprehensive aspects of sustainable urbanism can be distinguished: the relation between society and the research community, the complexity of urban resilience, and the role of 'landscape' in urbanism. 
Table 6. Sustainable urbanism and eco-cities key elements combined into principles and overarching concepts.

\begin{tabular}{|c|c|c|c|c|c|c|c|}
\hline Phase & Concept & Principle & Overarching & Principle & Object & City & Phase \\
\hline \multirow{3}{*}{ Negotiatism } & \multirow{3}{*}{$\begin{array}{l}\text { Co-design } \\
\text { Co-creation }\end{array}$} & \multirow{3}{*}{$\begin{array}{c}\text { People } \\
\text { Innovative design }\end{array}$} & \multirow{4}{*}{ Society } & People, co-creation & $\begin{array}{l}\text { Liveability } \\
\text { Local production } \\
\text { Identity }\end{array}$ & \multirow{4}{*}{$\begin{array}{l}\text { Social ecology } \\
\text { Health \& happiness } \\
\text { Cultural community }\end{array}$} & \multirow{4}{*}{$\begin{array}{c}\text { Fair Share/Equity and loca } \\
\text { economy/Community } \\
\text { development }\end{array}$} \\
\hline & & & & Innovative design & Urban governance & & \\
\hline & & & & People, co-design & Education & & \\
\hline Emergenism & Interventions & Innovative design & & & Lutucationt & & \\
\hline Ecosystem based & Metabolism & Close cycles & \multirow{3}{*}{ Complexity } & \multirow{3}{*}{ Flows/close cycles } & Renewable energy & & \multirow{4}{*}{ Standardised models } \\
\hline Antifragility & & Antifragile & & & $\begin{array}{l}\text { Low embodied energy } \\
\text { Passive design }\end{array}$ & $\begin{array}{l}\text { Sustainable city } \\
\text { Self-reliant city }\end{array}$ & \\
\hline Emergenism & Interventions & Space for the unknown & & & $\begin{array}{c}\text { Zero waste } \\
\text { Food } \\
\text { Water }\end{array}$ & $\begin{array}{c}\text { Resilient city } \\
\text { Regenerative city }\end{array}$ & \\
\hline \multirow[b]{2}{*}{ Conceptualism } & \multirow[b]{2}{*}{$\begin{array}{l}\text { Layers, } \\
\text { Casco } \\
\mathrm{S}_{2} \mathrm{~N}\end{array}$} & \multirow[b]{2}{*}{ Landscape as basis } & \multirow[b]{2}{*}{ Landscape } & \multirow[b]{2}{*}{$\begin{array}{l}\text { Landscape-based } \\
\text { design }\end{array}$} & $\begin{array}{l}\text { Climate } \\
\text { Landscape and biodiversity }\end{array}$ & $\begin{array}{l}\text { Carrying capacity, } \\
\text { metabolism } \\
\text { Zero-low-carbon City }\end{array}$ & \\
\hline & & & & & $\begin{array}{c}\text { Densification } \\
\text { Transport \& Travel }\end{array}$ & $\begin{array}{c}\text { Bioregional city } \\
\text { Green/Ubiquitous Eco-city } \\
\text { Smart city } \\
\text { Redesign of cities } \\
\text { Knowledge city }\end{array}$ & Technology and design \\
\hline Aesthetics & & & & & & & \multirow{2}{*}{ Environmental standard } \\
\hline Rationalism & & & & & & & \\
\hline
\end{tabular}




\subsection{Principles for Sustainable Urbanism}

The six principles for sustainable urbanism are the following:

1. Close cycles at the lowest possible scale. When the cycles of water, energy, and materials are closed, no waste streams are produced and the city is clean and has an efficient urban metabolism. The circularity provides abundant opportunities to create economic benefits. However, it is not always technically and financially most feasible to close cycles at the lowest possible scale. As Tillie et al. [94] and Van den Dobbelsteen [95] have pointed out, for energy solutions on different scales, up-scaling from the individual building can also lead to a balanced urban system;

2. Create spaces for the unknown. When redundancy becomes a standard part in urban design, the city has the flexibility to 'host' unprecedented events. If, for instance, a cyclone hits the city, there is space to temporarily store the accompanying water. Roggema [58] has identified this space as being 'unplanned';

3. Design anti-fragile spaces. Using this new concept to design places that improve the quality in the city when an event occurs. 'Ant-fragility is defined as a convex response to a stressor or source of harm (for some range of variation), leading to a positive sensitivity to increase in volatility (or variability, stress, dispersion of outcomes, or uncertainty, what is grouped under the designation "disorder cluster")' [65]. Applied in urban environments under stress of climate impacts, anti-fragility is the concept that urban environments become stronger than before through their response to climate events. In urbanism, this concept is ill-researched. However, it could potentially open new design pathways to create urban environments that not only could withstand or bounce back from climate disasters, but, as a result of the hazard, grow stronger;

4. Let people own their environment. When residents are part of the design process, they will create ownership over the changes and invest in their environment. Once residents own their environment, they will make sure it is maintained well [96]. The design charrette is a wonderful design method to develop designs in an inclusive way [97].

5. Use the landscape as the basis for urbanism. Landscape systems, such as the water system, ecology, and soil, create the conditions for urban occupancy. The values in the landscape then will determine the type of urban development. This is contrary to the current situation where the urban development dictates the landscape, e.g., overthrows the existing landscape values to create ordinary residential areas. Even in existing cities, the underlying landscape can be illuminated and brought to the surface to give the city extra ecological qualities.

6. Create innovative designs. The current conventions need to be broken if a sustainable city is to be developed. The existing procedures need to be bypassed using creative design approaches. For the development of regional plans, metropolitan spatial visions, district plans, and neighbourhood designs, a sabbatical detour can provide the space to think differently and the time to come up with alternative design propositions. Elements of a sabbatical detour are design competitions, an idea-generating charrette, designers in resident, exhibitions, and many other activities.

\subsection{Society Based, Complexity-Led, and Landscape-Driven}

The six design principles are interrelated and can be coherently summarized under three comprehensive concepts (see Table 6). 


\subsubsection{Society-Based Urbanism}

First of all, a key feature of an eco-city is a new relationship between Research/Governance and Society. Recent developments in the history of sustainable urbanism and the literature on eco-urbanism show that society increasingly plays the role of co-designer. The knowledgeable citizen has appeared and he/she is no longer satisfied with a role as respondent to plans made by professionals and/or the government. This implies a different role for the designer himself. Instead of being the 'planner who knows', the designer must become the 'planner who listens'. Before a design for a city is made, the designer as well as governing bodies will benefit from the knowledge and local expertise citizens have and can bring in the design process. The design then is enriched with additional understanding and emotional connotations of the city at stake. The research agenda therefore is not only determined by the funding agency, or the brains of the researcher, it will also be influenced through input from society. A recent planning process undertaken within the frame of 100 resilient cities in Sydney has revealed that citizens came up with approximately 400 ideas that make the city more resilient. Cross-pollination between research agendas and the civil agenda is necessary to grow a sustainable city.

\subsubsection{Complexity-Led Urbanism}

Secondly, the reviews have revealed that thinking about the city as a complex system $[57,98]$ is becoming more prominent. The different subsystems in the city, such as the transportation system, the energy system, and others, are increasingly seen as complex systems as such, but these feed in to the complexity of the city as a whole. The complexity of the entire city is difficult to grasp, as the interrelations, dependencies, and connectivity between all subsystems in the city are complex by nature. Earlier research [99] therefore proposed to deconstruct urban complexity in 15 systemic layers. Amongst these urban systems are the zero-carbon city, the climate resilient city, the densified city, the inhabitable city, the affordable city, the healthy city, the metabolic city, and more. Once these 'single-issue cities' have been designed to their ultimate, most resilient shape, they can be recombined. Then, the complexity can be reconstructed at the neighborhood scale, where local potentials and identities can be generated. Combining the specific features of the different layers for each location gives these places a very specific identity distinct from their neighbors. And, because the reconstructed complexity is based on the resiliency of individual layers, the overall capacity to adapt will increase both at the local level and for the entire metropolis. Because the set of 15 layers contains technical, socio-economic, and nature-based aspects, the combination of these layers provides a balanced and integrated way of looking at the entire city.

Research on these 15 layers is elaborate and the set-up of a rigorous data-base is time-consuming. Recently, investigations into the Zero-Carbon Metropolis of Sydney has led to an image of the first layer (Figure 1), which already can form the basis for further resilient designs at a lower scale [100]. This first layer has been developed by mapping the metropolitan renewable energy resources of the Greater Sydney area. These mappings of the wind potentials, hydropower potentials, solar potentials, and biomass potentials have been connected with the demand of households, public utilities, and industries under an ecological 'zero-carbon' lifestyle scenario. The integrated map shows the combination of these types of renewable energy supplies. 


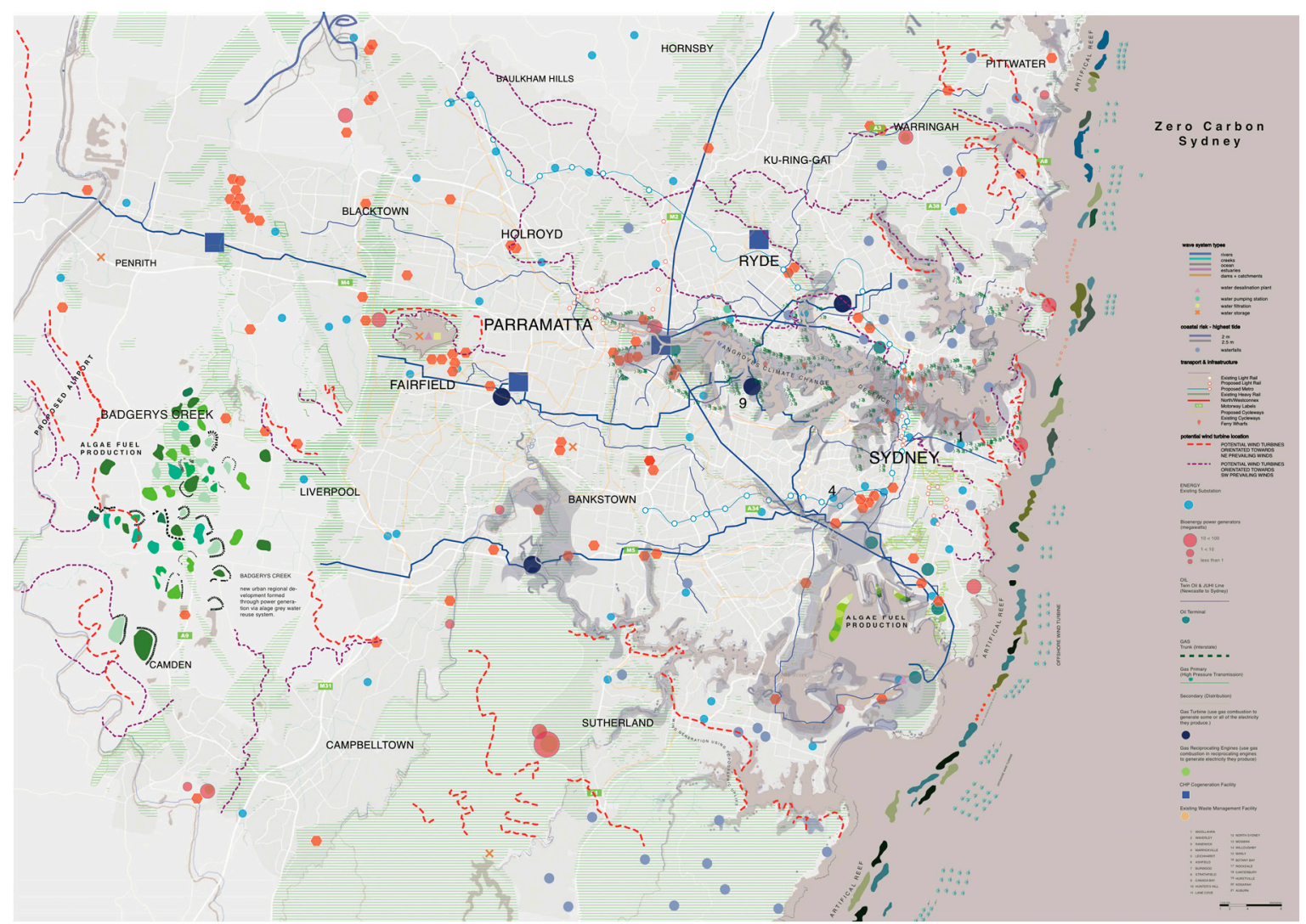

Figure 1. Map showing the Metropolis of Sydney as a Zero-Carbon area (Roggema et al., 2017).

\subsubsection{Landscape-Driven Design}

Landscape is everywhere around us, but in recent decades it has not played a dominant role in the growth of cities. The landscape is often neglected and replaced by an urban landscape that marginally contains elements of the former landscape. Both reviews illustrate that the landscape, represented through its elevation, water, ecology, is a crucial factor to create more sustainable cities. These factors, if not used as a determining factor in urban development, will eventually counterpunch at the city in the form of severe flooding, absence of agricultural fertility, or other disruptive processes. When these factors, however, are used as the basis for urban development, a truly sustainable city could emerge. The processes that drive the landscape are then also the drivers of urban development. If the flows of water form the basis for the urban lay-out, or if the connected habitats of natural ecologies are taken as the starting point of urban development, or if the natural gradients of higher oligotrophic grounds and the lower eutrophic soils are kept intact, the city that emerges builds on the natural richness of the landscape, creating a city in harmony with its environments. Recently, studies have been undertaken for the Badgerys Creek area, west of Sydney, where a new airport and a city with one million new inhabitants are planned to arise. If the urban growth is guided by the principles of the landscape, a very interesting and attractive urban environment can be designed (Figure 2). 


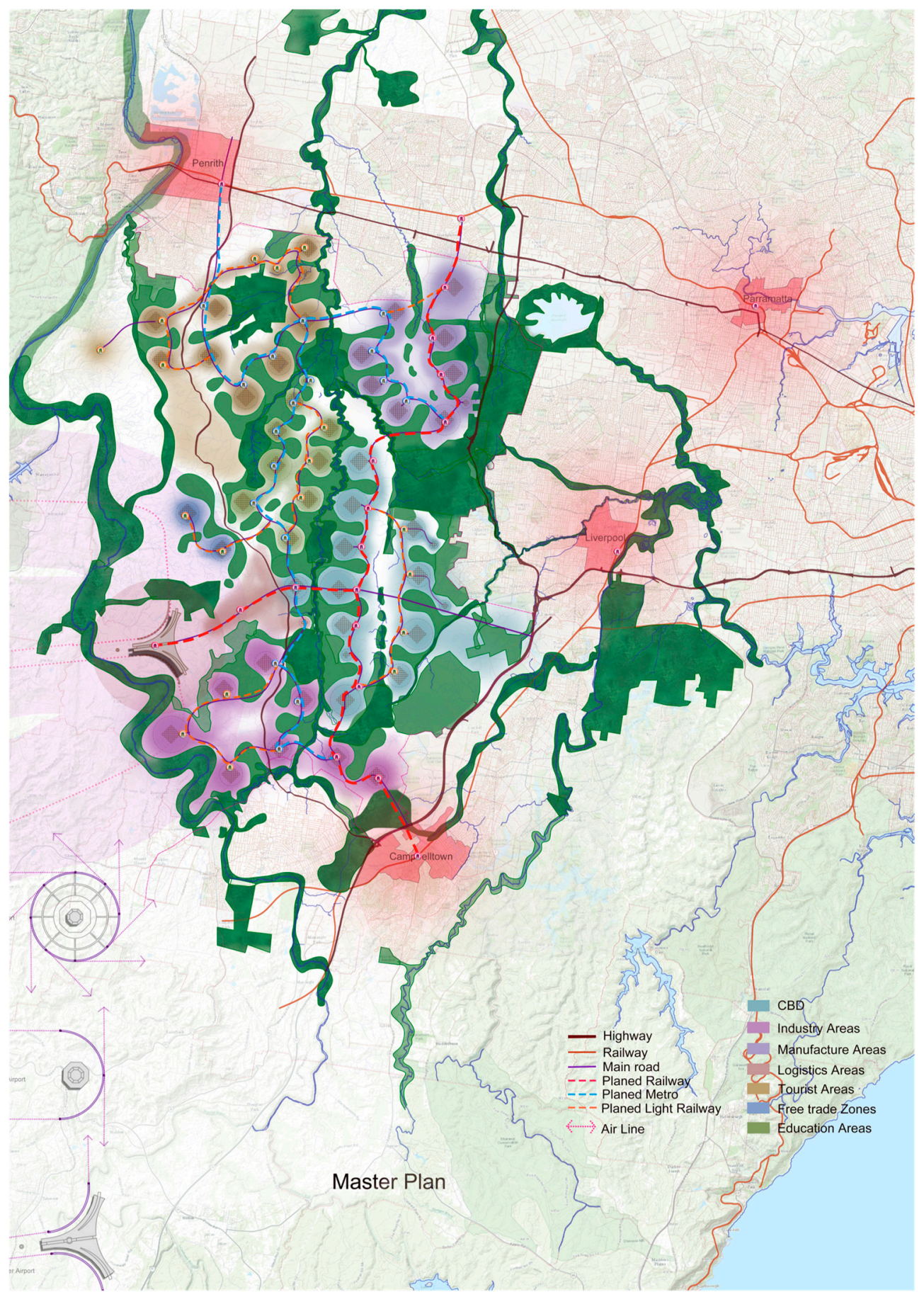

Figure 2. Plan for a landscape-driven urban design for Badgerys Creek (Source: Lingfen Xue, work resulting from the design studio GO WEST! Led by Rob Roggema and Craig Allchin, UTS, Autumn 2017).

\section{Discussion}

Sustainable urbanism is not only created by design. Economic factors, existing conventions, and limited scope of thinking could all lead to a way of city building that is not sustainable, despite all individual efforts to achieve exactly that. This article proposes to think in broader concepts, and to apply core sustainable design principles to create more sustainable cities. 
The methodology used in this article is predominantly based on an extensive literature review. This implies that other sources of information such as practical examples of sustainable urbanism, current research programs within H2020 or Australian CRC's (e.g., for Low Carbon Living) are excluded. For strengthening the theoretical contribution of this article, it is suggested to include these sources and amend the six principles accordingly.

The role of emergence and non-linearity in the development of sustainable urban designs is important. Systems thinking is the core of both landscape-driven urbanism, complexity-led urbanism, and socio-ecological systems thinking. The non-linearity of developments in the landscape is process-driven, and hence not simply logical. The interactions in society are in itself unpredictable due to the endless options of human interaction, hence the outcomes of co-creative processes are the result of an emergent process. The city itself is, as mentioned, a complex adaptive system, which makes the future of urban developments difficult to predict, and complexity theory forms the basis of modern city planning. All three overarching concepts find, therefore, their theoretical basis in systems thinking. The properties of systems can, therefore, be used in urbanism to create Master Plans, Urban Designs, and Precinct Plans that are more sustainable.

This also brings the discussion between sustainability and resilience to the fore. Whereas sustainability is mainly focused on the environmental quality of urban areas, the sustainability of its flows, and the way people can participate in the planning process [37], resilience focuses on the ability of the urban systems to bounce back and/or be less vulnerable for shocks influencing the urban system [25]. Hence, there is a certain overlap between these two concepts, especially when urban systems are set at the core of urbanism. Socio-ecological systems (people and networks, nature, water, energy, and mobility) can be both sustainable and resilient. Using a complex adaptive systems' planning approach to cities is, therefore, logical and preferable.

The three aspects, society-based, complexity-led, and landscape-driven are broad. They provide a way of thinking, and direct the process of designing a sustainable city. In this article, each of these aspects is described in more detail to support urbanists to create sustainable cities. These aspects are also described to a certain abstraction, as each of them can be applied in practice in a way that suits the specific context. Whereas society-based directs the process and the role of the designer in the process, complexity-led and landscape-driven contain more guidance on the content.

The six principles require application and further elaboration in concrete case studies to test and investigate their implications. The principles are each covering a field of research that contributes to developing a sustainable city.

Based on the three aspects and six principles, a definition for sustainable urbanism can be developed: "Sustainable urbanism is society-based, complexity-led, and landscape-driven, and it closes cycles at the best possible scale, creates spaces for the unknown, designs anti-fragile areas, lets people own their environment, uses the landscape as the basis for design, and creates innovative rule-breaking designs".

\section{Conclusions}

This article started with two reviews of literature, one on the historic development of the concept of sustainable urbanism and one on recent literature about green eco-cities. These reviews revealed that for the design of a sustainable city, three aspects and six principles need to be taken into account.

Each city should organize a process in which the society is as agenda-setting as the research community.

Every city should deconstruct its complex urban systems and recombine them at the neighborhood level.

Each city should base its urban growth and redevelopment on the landscape, giving space to the natural conditions of an area to shape a harmonious city. 
In order to be effective in creating this sustainable city, every design should strive for closing cycles, building in redundancy, creating anti-fragility, having the courage to listen to its citizens, and using the landscape as a basis for innovative, rule-breaking designs.

Conflicts of Interest: The author declares no conflict of interest.

\section{References}

1. Intergovernmental Panel on Climate Change (IPCC). Climate Change 2014: Synthesis Report; Contribution of Working Groups I, II and III to the Fifth Assessment Report of the Intergovernmental Panel on Climate Change; Core Writing Team, Pachauri, R.K., Meyer, L.A., Eds.; IPCC: Geneva, Switzerland, 2014; p. 151.

2. Roggema, R. The future of sustainable urbanism: A redefinition. City Territ Archit. 2016, 3. [CrossRef]

3. Rittel, H.; Webber, M. Dilemmas in a general theory of planning. Policy Sci. 1973, 4, 155-169, Reprinted in Developments in Design Methodology; Cross, N., Ed.; Wiley: Chichester, UK, 1984; pp. 135-144. [CrossRef]

4. VROM-raad. De Hype Voorbij, Klimaatverandering als Structureel Ruimtelijk Vraagstuk; advies 060; VROM-raad: Den Haag, The Netherlands, 2007.

5. Commonwealth of Australia. Tackling Wicked Problems; a Public Policy Perspective; Australian government/Australian Public Service Commission: Canberra, Australia, 2007.

6. Allen, C.; Clouth, S. A Guidebook to the Green Economy; UNDESA: New York, NY, USA, 2012.

7. Foxon, T.J.; Hammond, G.P.; Pearson, P.J. Developing transition pathways for a low carbon electricity system in the UK. Technol. Forecast. Soc. Chang. 2010, 77, 1203-1213. [CrossRef]

8. Bulkeley, H.; Broto, V.C.; Hodson, M.; Marvin, S. (Eds.) Cities and Low Carbon Transitions; Routledge: London, UK, 2010.

9. United Nations. World Urbanization Prospects. The 2007 Revision; United Nations: New York, NY, USA, 2008.

10. Kreimer, A.; Arnold, M.; Carlin, A. (Eds.) Building Safer Cities: The Future of Disaster Risk; The International Bank for Reconstruction and Development, The World Bank: Washington, DC, USA, 2003.

11. Glaser, B.; Strauss, A. The Discovery of Grounded Theory; Aldine: Chicago, IL, USA, 1967.

12. Corbin, J.; Strauss, A. Basics of Qualitative Research; Sage Publications: Thousand Oaks, CA, USA, 2008.

13. Larco, N. Sustainable urban design-A (draft) framework. J. Urban Des. 2016, 21, 1-29. [CrossRef]

14. Girardet, H. The GAIA Atlas of Cities: New Directions for Sustainable Urban Living; Gaia Books Limited: London, UK, 1996.

15. Howard, E. Garden Cities of Tomorrow; S. Sonnenschein \& Co., Ltd.: London, UK, 1902.

16. Wise, E. A gradual awakening: Broadacre city and a new American agrarianism. Berkeley Plan J. 2013, 26, 133-149.

17. Cohen, J.-L.; Benton, T. (Eds.) Le Corbusier Le Grand; Phaidon Press Limited: London, UK, 2008.

18. Nicholls, R.J. Coastal megacities and climate change. GeoJournal 1995, 37, 369-379. [CrossRef]

19. Donatiello, J.E. The world's population: An encyclopedia of critical issues, crises, and ever-growing countries. Ref. User Serv. Q. 2015, 54, 85. [CrossRef]

20. Farr, D. Sustainable Urbanism. Urban Design with Nature; John Wiley and Sons Inc.: Hoboken, NJ, USA, 2008.

21. Beatley, T. Green Urbanism: Learning from European Cities; Island Press: Washington, DC, USA, 2000.

22. Beatley, T. Biophilic Cities: Integrating Nature into Urban Design and Planning; Island Press: Washington, DC, USA, 2010.

23. Mostafavi, M. Why Ecological Urbanism? Why Now? In Ecological Urbanism; Mostafvai, M., Doherty, G., Eds.; Lars Müller Publishers: Baden, Switzerland, 2010.

24. Waldheim, C. Landscape as Urbanism. In Landscape as Urbanism Reader; Waldheim, C., Ed.; Princeton Architectural Press: New York, NY, USA, 2006; pp. 21-34.

25. Newman, P.; Beatley, T.; Boyer, T. Resilient Cities; Island Press: Washington, DC, USA, 2009.

26. Duany, A.; Speck, J.; Lydon, M. The Smart Growth Manual; McGraw-Hill Education: New York, NY, USA, 2009.

27. Haas, T. Sustainable Urbanism and Beyond; Rizzoli: New York, NY, USA, 2012.

28. Kriens, I.; Klaasen, I.T.; Rooij, R.M. De Kern van Ruimtelijke Planning and Strategie. Ruimte en Maatschappij; Technische Universiteit Delft: Delft, The Netherlands, 2008.

29. Morgan, M.H. Vitruvius. The Ten Books on Architecture; Harvard University Press: Cambridge, MA, USA; Oxford University Press: London, UK, 2001. 
30. Ministerie van Landbouw Natuurbeheer en Visserij. Nota Landschap; Ministerie van LNV: Den Haag, The Netherlands, 1992.

31. Gunder, M. Fake it until you make it, and then ... . Plan Theory 2011, 10, 201-212. [CrossRef]

32. Sullivan, L. The Tall Office Building Artistically Considered; Lippincott's Monthly Magazine: New York, NY, USA, 1896.

33. McHarg, I.L. Design with Nature; Natural History Press: New York, NY, USA, 1969.

34. Van Schaick, J.; Klaasen, I.T. The Dutch layers approach to spatial planning and design: A fruitful planning tool or a temporary phenomenon? Eur. Plan. Stud. 2011, 19, 1775-1796. [CrossRef]

35. Priemus, H. The network approach: Dutch spatial planning between substratum and infrastructure networks. Eur. Plan. Stud. 2007, 15, 667-686. [CrossRef]

36. Sijmons, D. Het Casco-Concept, een Benaderingswijze Voor de Landschapsplanning; Ministerie van LNV, directie NBLF: Utrecht, The Netherlands, 1992.

37. Tjallingii, S.P. Ecopolis: Strategies for Ecologically Sound Urban Development; Backhuys Publishers: Leiden, The Netherlands, 1995.

38. Tjallingii, S. Planning with water and traffic networks. Carrying structures of the urban landscape. Res. Urban Ser. 2015, 3, 57-80. [CrossRef]

39. Teeuw, P. Duurzame Ideeën \% DCBA Methodiek: Ambitie Stellen Volgens de Viervarianten-Methode; AEneas, Boxtel: Hertogenbosch, The Netherlands, 2010.

40. Sanders, E.B.N.; Stappers, P.J. Co-creation and the new landscape of design. CoDesign 2008, 4, 5-18. [CrossRef]

41. Roggema, R.; Martin, J.; Arcari, P.; Clune, S.; Horne, R. Design-Led Decision Support Process and Engagement; VCCCAR: Melbourne, Australia, 2013.

42. Roggema, R.; Vos, L.; Martin, J. Resourcing local communities for climate adaptive designs in Victoria, Australia. Chin. J. Popul. Resour. Manag. 2014, 12, 210-226. [CrossRef]

43. Roggema, R.; Martin, J.; Vos, L. Governance of Climate Adaptation in Australia: Design Charrettes as Creative Tool for Participatory Action Research. In Action Research for Climate Change Adaptation: Developing and Applying Knowledge for Governance; Van Buuren, A., Eshuis, J., van Vliet, M., Eds.; Routledge: London, UK, 2014; pp. 92-108.

44. Surowiecki, J. The Wisdom of Crowds: Why the Many Are Smarter Than the Few; Little Brown: Boston, MA, USA, 2004.

45. Tomásek, W. Die Stadt als Oekosystem; Úberlegungen zum Vorentwurf Landschafsplan Köln (The city as ecosystem; considerations about the scheme of the Landscape design Cologne). Landsch. Stadt 1979, 11, 51-60.

46. Wolman, A. The metabolism of cities. Sci. Am. 1965, 213, 179-190. [CrossRef] [PubMed]

47. Newman, P.W.G. Sustainability and cities: Extending the metabolism model. Landsc. Urban Plan. 1999, 44, 219-226. [CrossRef]

48. Kennedy, C.; Cuddihy, J.; Engel-Yan, J. The changing metabolism of cities. J. Ind. Ecol. 2007, 11, 43-59. [CrossRef]

49. Kennedy, C.; Pincetl, S.; Bunje, P. The study of urban metabolism and its applications to urban planning and design. Environ. Pollut. 2010, 159, 1965-1973. [CrossRef] [PubMed]

50. Shafie, F.A.; Dasimah, O.; Karuppannanb, S. Urban metabolism: A research methodology in urban planning and environmental assessment. In Proceedings of the 1st International Conference on Research Methodology for Built Environment and Engineering, Kuala Lumpur, Malaysia, 17-18 December 2013.

51. Kristinsson, J. Integrated Sustainable Design; Van den Dobbelsteen, A., Ed.; Delft Digital Press: Delft, The Netherlands, 2012.

52. Prigogine, Y.; Stengers, I. Order out of Chaos. Man's New Dialogue with Nature; Bantam Books Inc.: New York, NY, USA, 1984.

53. Mitchell Waldrop, M. Complexity. The Emerging Science at the Edge of Order and Chaos; Simon and Schuster Paperbacks: New York, NY, USA, 1992.

54. Kauffman, S.A. The Origin of Order: Self-Organisation and Selection in Evolution; Oxford University Press: New York, NY, USA, 1993.

55. Kauffman, S. At Home in the Universe; Oxford University Press: Oxford, UK, 1995. 
56. Cohen, J.; Stewart, I. The Collapse of Chaos: Discovering Simplicity in a Complex World; Penguin Group Ltd.: London, UK, 1994.

57. Portugali, J. Self-Organisation and the City; Springer: Berlin, Germany, 2000.

58. Roggema, R. Swarm Planning: The Development of a Spatial Planning Methodology to Deal with Climate Adaptation. Ph.D. Thesis, Delft University of Technology, Delft, The Netherlands, 2012.

59. Waterman, R.E. Integrated Coastal Policy via Building with Nature. Ph.D. Thesis, Delft University of Technology, Delft, The Netherlands, 2010.

60. Ryan, C. Eco-acupuncture: Designing and facilitating pathways for urban transformation, for a resilient low-carbon future. J. Clean. Prod. 2013, 50, 189-199. [CrossRef]

61. Ryan, C.; Biggs, C.; Trudgeon, M. Eco-acupuncture and greenaissance: Designing urban interventions for resilient post-carbonaceous futures, from Victoria (Australia) to Florence (Italy). In Proceedings of the State of Australian Cities Conference, Sydney, Australia, 26-29 November 2013.

62. Roggema, R. Towards enhanced resilience in city design: A proposition. Land 2014, 3, 460-481. [CrossRef]

63. Roggema, R. Three urbanisms in one city: Accommodating the paces of change. J. Environ. Prot. 2015, 6, 946-956. [CrossRef]

64. Russell, J.S. The Agile City. Building Well-Being and Wealth in an Era of Climate Change; Island Press: Washington, DC, USA, 2011.

65. Taleb, N.N. Antifragile—Things That Gain from Disorder; Random House: New York, NY, USA, 2012.

66. Ellis, C. Landscape Urbanism and New Urbanism: A View of the Debate. J. Urban Des. 2015, 20, 303-307. [CrossRef]

67. Kahn, M.E. Green Cities Urban Growth and the Environment; Brookings: Washington, DC, USA, 2006.

68. Lehmann, S. Green Urbanism: Formulating a Series of Holistic Principles. Sapiens 2010, 3, 1-17.

69. Beck, U. Risk Society. Towards a New Modernity; Sage: London, UK, 2000.

70. Joss, S. Eco-cities: The mainstreaming of urban sustainability-Key characteristics and driving forces. Int. J. Sustain. Dev. Plan. 2011, 6, 268-285. [CrossRef]

71. Rapoport, E.; Vernay, A.-L. Defining the Eco-City: A Discursive Approach; International Ecocities Initiative; University of Westminster: London, UK, 2014. Available online: https://www.westminster.ac.uk/file/ 42096/download (accessed on 15 May 2017).

72. Van den Dobbelsteen, A.; Jansen, S.; van Timmeren, A.; Roggema, R. Energy Potential Mapping-A systematic approach to sustainable regional planning based on climate change, local potentials and exergy. In Proceedings of the CIB World Congress, Cape Town, Africa, 14-18 May 2007.

73. Lehmann, S. The Principles of Green Urbanism. Transforming the City for Sustainability; Earthscan: London, UK, 2010.

74. Haughton, G. Developing sustainable urban development models. Cities 1997, 14, 189-195. [CrossRef]

75. De Jong, M.; Joss, S.; Schraven, D.; Zhan, C.; Weinen, M. Sustainable-smart-resilient-low carbon-eco-knowledge cities; making sense of a multitude of concepts promoting sustainable urbanization. J. Clean. Prod. 2015, 109, 25-38. [CrossRef]

76. Townsend, A.M. Smart Cities. Big Data, Civic Hackers, and the Quest for a New Utopia; W.W. Norton Inc.: New York, NY, USA, 2014.

77. Caragliu, A.; Del Bo, C.; Nijkamp, P. Smart Cities in Europe. J. Urban Technol. 2011, 18, 65-82. [CrossRef]

78. Yigitcanlar, T.; Velibeyogly, K.; Baum, S. (Eds.) Knowledge-Based Urban Development: Planning and Applications in the Information Era; IGI Global: Hershey, PA, USA, 2008.

79. Jabareen, Y. Planning the resilient city: Concepts and strategies for coping with climate change and environmental risk. Cities 2013, 31, 220-229. [CrossRef]

80. Leichenko, R. Climate change and urban resilience. Curr. Opin. Environ. Sustain. 2011, 3, 164-168. [CrossRef]

81. Register, R. Ecocity Berkeley: Building Cities for a Healthy Future; North Atlantic Books: Berkeley, CA, USA, 1973.

82. Ecobuilders (Undated). What Is an Ecocity? Available online: http://www.ecocitybuidlers.org/what-is-anecocity/ (accessed on 12 April 2017).

83. Roselund, M. Dimensions of the eco-city. Cities 1997, 14, 197-202. [CrossRef]

84. World Commission on Environment and Development (WCED). Our Common Future; Oxford University Press: New York, NY, USA, 1987.

85. Sale, K. Dwellers in the Land: The Bioregional Vision; Sierra Club: San Francisco, CA, USA, 1985.

86. Capra, F.; Spretnak, C. Green Politics: The Global Promise; Dutton: New York, NY, USA, 1984. 
87. Van Timmeren, A.; Henriquez, L.; Reynolds, A. Ubikquity $\mathcal{E}$ the Illuminated City; TU Delft: Delft, The Netherlands, 2015.

88. Joss, S.; Cowley, R.; Tomozeiu, D. Towards the 'ubiquitous eco-city': An analysis of the internationalisation of eco-city policy and practice. Urban Res. Pract. 2013, 6, 54-74. [CrossRef]

89. Howarth, L. Ecopolis, the Emergence of Regenerative Cities. The Ecologist. Available online: http:/ / www. theecologist.org/News/news_analysis /2000416/ecopolis_the_emergence_of_regenerative_cities.html (accessed on 12 April 2017).

90. Boselli, F. Cities Must Be Regenerative. But What Kind of Regeneration Are We Actually Talking About? World Future Council. 2016. Available online: https://www.worldfuturecouncil.org/cities-mustregenerative-kind-regeneration-actually-talking/ (accessed on 12 April 2017).

91. ReGen Villages Holding. REGENVILLAGES. 2016. Available online: http://www.regenvillages.com (accessed on 18 May 2017).

92. Kenworthy, J.R. The eco-city: ten key transport and planning dimensions for sustainable city development. Environ. Urban. 2006, 18, 67-85. [CrossRef]

93. Bioregional. The BedZED Story. The UK's First Large Scale, Mixed-Use Eco-Village; Bioregional Development Group: London, UK, 2016.

94. Tillie, N.; Van Den Dobbelsteen, A.; Doepel, D.; Joubert, M.; De Jager, W.; Mayenburg, D. Towards $\mathrm{CO}_{2}$ Neutral Urban Planning: Presenting the Rotterdam Energy Approach and Planning (REAP). J. Green Build. 2009, 4, 103-112. [CrossRef]

95. Van den Dobbelsteen, A.; Wisse, K.; Doepel, D.; Tillie, N. REAP2-new concepts for the exchange of heat in cities. In Proceedings of the 4th CIB Conference Smart and Sustainable Built Environments, Sao Paulo, Brazil, 27-29 June 2012.

96. Western Australian Planning Commission. Designing out Crime. Planning Guidelines; State of Western Australia: Perth, Australia, 2009.

97. Roggema, R. The Design Charrette: Ways to Envision Sustainable Futures; Springer: Dordrecht, The Netherlands; Heidelberg, Germany; London, UK, 2013; p. 335.

98. Portugali, J. Complexity theory as a link between space and place. Environ. Plan. A 2006, 38, 647-664. [CrossRef]

99. Roggema, R.; Thomas, L. Critical mapping for transformational cities. In Proceedings of the Passive and Low Energy Architecture (PLEA 2017), Edinburgh, UK, 3-5 July 2017.

100. Roggema, R.; King, L.; van den Dobbelsteen, A. Towards Zero-Carbon metropolitan regions: The example of Sydney. Energies 2017, forthcoming. 